\title{
INEQUALITIES CORRESPONDING TO \\ THE CLASSICAL JENSEN'S INEQUALITY
}

\section{LÁSZLó HORVÁTH}

Abstract. In this paper some integral inequalities are proved in probability spaces, which go back to some discrete variants of the Jensen's inequality. Especially, we refine the classical Jensen's inequality. Convergence results corresponding to the inequalities are also studied.

Mathematics subject classification (2000): 26D15, 60E15.

Keywords and phrases: products of probability spaces, the classical Jensen's inequality.

\section{REFERENCES}

[1] H. BAuer, Probability theory, de Gruyter Stud. Math. 23. Walter de Gruyter, Berlin-New York, 1996.

[2] S. S. DRAGOMIR, A further improvement of Jensen's inequality, Tamkang J. Math., 25, 1 (1994), 29-36.

[3] E. Hewitt And K. R. Stromberg, Real and abstract analysis, Graduate Text in Mathematics 25, Springer-Verlag, Berlin-Heidelberg-New York, 1965.

[4] J. E. PeČArić And S. S. Dragomir, A refinements of Jensen inequality and applications, Studia Univ. Babeş-Bolyai, Mathematica, 24, 1 (1989), 15-19.

[5] D. S. Mitrinović, J. E. PeČArić And A. M. Fink, Classical and new inequalities in analysis, Kluwer Academic, Dordrecht, 1993. 